\title{
ANALYSIS OF QUANTITATIVE METHODS OF RISK ASSESSMENT AND SELECTION OF OPTIMAL METHOD USING VENTURE INVESTMENT IN INNOVATIVE PROJECTS IN CONSTRUCTION
}

\author{
Valeria PUGACHEVA \\ Russian Plekhanov University of Economics, Russian Federation \\ Corresponding author e-mail: Lero4ka1820@yandex.ru
}

\begin{abstract}
One of the main factors that constrains using of venture investment in innovative projects in the field of construction is high risk of this type of investment. Thus, the problem of risk assessment is relevant in the venture investment of innovative projects. First of all, it should be noted that the risks in the construction industry have considerable specificity and heterogeneity. Real options approach is an important tool with venture investment at all stages. It can be widely used in innovative projects in construction for accurate risk assessment.
\end{abstract}

Keywords: Risks, venture investment, quantitative risk assessment, real options method, models of the Black - Scholes and the binomial.

\section{INTRODUCTION}

One of the main factors which holds back the activity of using venture capital in innovative projects in the construction is the high risk of this type of investment, in addition to this factor there can be unstable economic situation, lack of regulatory framework and lack of qualified personnel. Therefore the problem of assessing risks in innovative projects is relevant when using venture investment (Ernst \& Young Global Limited using Russian Venture Company, 2014).

The research of existing methods of quantitative risk analysis made by the author shows that in the risk assessment of an innovative project using venture investment- it is necessary to assess all of the existing methods and choose the one that would take into account all the specifics of venture investment, and in addition can be used for the construction industry where the risk factor (uncertainty), is large, and the degree of the study of this problem is insufficient (Vladimirova \& Pugacheva, 2013). This is due to the fact that the most innovative projects in construction are realized at the expense of traditional sources of investment - bank loan. 


\section{ANALYSIS OF METHODS OF RISK ASSESSMENT IN CONSTRUCTION USING VENTURE INVESTMENT}

First of all, the risks in the construction industry have considerable specificity and diversity. To a large extent they relate to the volatility and oscillatory nature of the economic situation, at macro and at the industry level. In addition, the construction combines and covers many varied connections of over seventy branches of national economy, supplying the construction with their products. Implementation of innovative projects in such conditions is associated with an increased risk, especially if it involves the participation of a venture investor in the project (The Federal Agency for Innovation and Development of Economic and Social projects, n.d.). This is due to the high uncertainty of both external and internal environment in which the project is implemented. In this situation, the traditional methods of assessing the effectiveness of risk lead to a significant underestimation of the effectiveness of innovative projects due to a number of assumptions that distort the impact of such projects. The disadvantages of traditional project performance evaluation methods are static, requiring determinism and certainty of the input data. Correct assessment of the impact of uncertainty and risk on project results plays major role in improving the objectivity of an efficiency estimation. Currently, only a few methods are widely used risk analysis in venture investing. These include:

- adjusted discount rate method;

- analysis of sensitivity of performance criteria;

- scenario method;

- decisions trees;

- real options.

On the basis of comparative analysis and ranging methods, we choose the most suitable one with the risk factor in the conditions of an innovative project with the participation of venture investment (see Table 1). First, it should developed a comparative description of these methods. Secondly, there should be a ranging, evaluating each method using a 5 point scale. Also, each method should be decreased by distributing evaluation.

The comparative analysis of the above mentioned methods showed to be effective and confirmed that there are prospects of using real options in the evaluation of innovative projects in the conditions of high uncertainty and risk. The advantages of real option are to integrate the multi-variant of the project, strategic value, the value of knowledge, flexibility in the project management of the project. 
Table 1. Comparative Features of Methods of Risk Analysis

\begin{tabular}{|c|c|c|c|c|}
\hline & Advantages & Disadvantages & $\begin{array}{c}\text { Ranging } \\
(1-5)\end{array}$ & $\begin{array}{c}\text { Final } \\
\text { assessment }\end{array}$ \\
\hline $\begin{array}{l}\text { Adjusted } \\
\text { discount rate } \\
\text { method }\end{array}$ & $\begin{array}{l}\text { Easy payment } \\
\text { Apprehensibility and } \\
\text { accessibility of the } \\
\text { results }\end{array}$ & $\begin{array}{l}\text { Does not give information } \\
\text { about the degree of risk } \\
\text { The results essentially depend } \\
\text { only on the size of the risk } \\
\text { premium. } \\
\text { The increase in risk over time } \\
\text { with a constant factor } \\
\text { Does not carry information } \\
\text { about the probability of } \\
\text { distribution of future payment } \\
\text { flows and does not allow to } \\
\text { get their assessment }\end{array}$ & 1 & 5 \\
\hline $\begin{array}{l}\text { Analysis of } \\
\text { sensitivity of } \\
\text { performance } \\
\text { criteria }\end{array}$ & $\begin{array}{l}\text { It is a good } \\
\text { illustration of the } \\
\text { effect of individual } \\
\text { factors on the starting } \\
\text { data at the end of the } \\
\text { project }\end{array}$ & $\begin{array}{l}\text { Changing one factor } \\
\text { considered in isolation }\end{array}$ & 2 & 4 \\
\hline $\begin{array}{l}\text { Scenario } \\
\text { method }\end{array}$ & $\begin{array}{l}\text { The deviation of a } \\
\text { productive indicator } \\
\text { is calculated taking } \\
\text { into account mutual } \\
\text { influence of operating } \\
\text { factors } \\
\text { Assists in getting } \\
\text { sufficient visual } \\
\text { pattern for a variety } \\
\text { of options for the } \\
\text { implementation of } \\
\text { projects } \\
\text { It provides } \\
\text { information about the } \\
\text { sensitivity and } \\
\text { possible deviations } \\
\text { Can be realized by } \\
\text { Project Expert, Excel }\end{array}$ & $\begin{array}{l}\text { Insufficient attention to } \\
\text { interdependence and } \\
\text { interaction of different factors } \\
\text { influencing the course of } \\
\text { events- and development of } \\
\text { the dynamics of the situation }\end{array}$ & 4 & 2 \\
\hline $\begin{array}{l}\text { Decision } \\
\text { trees }\end{array}$ & $\begin{array}{l}\text { Consistently } \\
\text { estimated } \\
\text { consequences of each } \\
\text { possible initiating } \\
\text { event and the } \\
\text { estimated maximum } \\
\text { probability of } \\
\text { ultimate objective }\end{array}$ & $\begin{array}{l}\text { Significant time spent on } \\
\text { research (increases the amount } \\
\text { of calculations for shuffling } \\
\text { all possible options, the total } \\
\text { amount of which can reach } \\
\text { tens, hundreds) }\end{array}$ & 3 & 3 \\
\hline
\end{tabular}




\begin{tabular}{|l|l|l|c|c|}
\hline Real options & \multicolumn{1}{|c|}{ Advantages } & $\begin{array}{l}\text { Focused on } \\
\text { increasing } \\
\text { shareholder value } \\
\text { The mechanism of } \\
\text { investment decision- } \\
\text { making has become } \\
\text { more simple and } \\
\text { understandable } \\
\text { amount of information } \\
\text { The threat of excessive } \\
\text { optimism and overestimation } \\
\text { of the project }\end{array}$ & $\begin{array}{l}\text { Final } \\
\text { assessment }\end{array}$ \\
$\begin{array}{l}\text { Greater importance is } \\
\text { given to the decisions } \\
\text { related to the } \\
\text { termination of } \\
\text { ineffective projects or } \\
\text { expansion projects } \\
\text { that may be profitable } \\
\text { in the future }\end{array}$ & & 5 & 1 \\
\hline
\end{tabular}

Note: compiled by the author.

\section{PROCEDURES OF USING REAL OPTION}

\subsection{Definition of Real Option and its Place in the Innovative Project in Construction Using Venture Investment}

The real option in innovative project in construction is the acquisition right during certain costs, associated with the implementation of the project management solution in the future that is accompanied by a reduction in the uncertainty of the future in the period between the acquisition of option and the decision on execution of law. On the basis of reducing uncertainty an interim decision can taken regarding continuation, postponement or refusal of the investment or change of the direction of the project (Zakieva, 2012).

The real value of the option is the modern cash flow costs resulting from the accounting execution capabilities or default option (Zakieva, 2012). If the option is not executed, the cash flow is negative and equal to the option premium. If the option is executed, the cash flow is taking place for the option.

The premium of real option is the cost of acquisition according to the relevant law. In some cases, the right to perform an action or the possibility of it is to make the acquisition of information through the implementation of analytical work. The results of these studies will be the basis for appropriate activity in the implementation of an innovative project in construction, and the cost of the activity will be the premium of real option.

The stage of realizing innovative project in construction since the release acquisition of real options, their costs and the amount of premium are considered (see Table 2). 
Table 2. Real Option in Innovative Project in Construction

\begin{tabular}{|c|c|c|c|}
\hline Steps & Real option & Real option value & Investments \\
\hline \multicolumn{4}{|l|}{ 1. Pre-design stage } \\
\hline \multirow{2}{*}{$\begin{array}{l}\text { Identifying problems } \\
\text { in economic activity } \\
\text { that require scientific } \\
\text { and technical } \\
\text { solutions. } \\
\text { Identification of the } \\
\text { company's needs in } \\
\text { the new technology, } \\
\text { technology and other } \\
\text { results of innovative } \\
\text { projects. } \\
\text { Monitoring of } \\
\text { perspective scientific } \\
\text { and technical } \\
\text { developments. } \\
\text { Analysis of } \\
\text { innovation offers of } \\
\text { scientific, educational } \\
\text { and other } \\
\text { organizations. }\end{array}$} & $\begin{array}{l}\text { Delayed investment } \\
\text { in Stage } 2\end{array}$ & $\begin{array}{l}\text { The increase of net } \\
\text { present value (NPV) } \\
\text { by more successful } \\
\text { timing of the basic } \\
\text { investments, net loss } \\
\text { of cash streams } \\
\text { during the delay of } \\
\text { periods }\end{array}$ & \multirow{2}{*}{$\begin{array}{l}\text { Costs of collecting } \\
\text { information and } \\
\text { analytical operations }\end{array}$} \\
\hline & $\begin{array}{l}\text { Refusing from } \\
\text { investment in } \\
\text { Stage } 2\end{array}$ & $\begin{array}{l}\text { Value of potential } \\
\text { losses because of } \\
\text { untimely investment }\end{array}$ & \\
\hline \multicolumn{4}{|l|}{ 2. Initiation stage } \\
\hline $\begin{array}{l}\text { 2.1.Appointing of the } \\
\text { performers }\end{array}$ & - & - & \multirow{4}{*}{$\begin{array}{l}\text { Investments in } \\
\text { personnel, } \\
\text { knowledge, } \\
\text { equipment, creating } \\
\text { infrastructure, } \\
\text { workers' salary, } \\
\text { overhead costs }\end{array}$} \\
\hline $\begin{array}{l}\text { 2.2. Defining of goals } \\
\text { and objectives of } \\
\text { innovative project }\end{array}$ & - & - & \\
\hline $\begin{array}{l}\text { 2.3. Description of } \\
\text { the perfected } \\
\text { production and } \\
\text { management } \\
\text { processes }\end{array}$ & - & - & \\
\hline 2.4. Idea generation & - & - & \\
\hline \multirow[t]{2}{*}{$\begin{array}{l}\text { 2.5. Selecting of the } \\
\text { ideas }\end{array}$} & $\begin{array}{l}\text { Repeated idea } \\
\text { generation }\end{array}$ & $\begin{array}{l}\text { The increase of NPV } \\
\text { by developing more } \\
\text { promising ideas }\end{array}$ & $\begin{array}{l}\text { Repeated financing } \\
\text { Stage } 2.4 \text { "Idea } \\
\text { generation" }\end{array}$ \\
\hline & $\begin{array}{l}\text { Refusing from } \\
\text { investment in } \\
\text { Stage } 3\end{array}$ & $\begin{array}{l}\text { Potential value } \\
\text { losses from } \\
\text { investments in the } \\
\text { following stages }\end{array}$ & $\begin{array}{l}\text { Workers' salary, } \\
\text { overhead costs }\end{array}$ \\
\hline
\end{tabular}




\begin{tabular}{|c|c|c|c|}
\hline Steps & Real option & Real option value & Investments \\
\hline $\begin{array}{l}\text { 2.6. Planning of the } \\
\text { implementation of the } \\
\text { program: } \\
\text { defining of technical, } \\
\text { economic and } \\
\text { organizational } \\
\text { activities, leading to } \\
\text { the establishment and } \\
\text { use of innovative } \\
\text { product; } \\
\text { the formation of } \\
\text { technical } \\
\text { specifications for } \\
\text { R\&D; } \\
\text { preparation of } \\
\text { research plan; } \\
\text { sizing of the project } \\
\text { financing and each } \\
\text { phase of the work } \\
\text { plan }\end{array}$ & - & - & $\begin{array}{l}\text { Workers' salary, } \\
\text { overhead costs }\end{array}$ \\
\hline \multirow[t]{2}{*}{ 2.7. Feasibility study } & $\begin{array}{l}\text { Delay investment in } \\
\text { Stage } 3\end{array}$ & $\begin{array}{l}\text { The increase of NPV } \\
\text { by more successful } \\
\text { timing R\&D for net } \\
\text { loss cash flows } \\
\text { deferment periods }\end{array}$ & \multirow{2}{*}{$\begin{array}{l}\text { Cost of analytical } \\
\text { work, the cost of } \\
\text { collection and } \\
\text { processing }\end{array}$} \\
\hline & $\begin{array}{l}\text { Refusing from } \\
\text { investment in } \\
\text { Stage } 3\end{array}$ & $\begin{array}{l}\text { Value potential } \\
\text { losses from } \\
\text { investments in the } \\
\text { following stages }\end{array}$ & \\
\hline \multicolumn{4}{|l|}{ 3. R\&D stage } \\
\hline $\begin{array}{l}\text { 3.1. Scientific } \\
\text { research work }\end{array}$ & $\begin{array}{l}\text { Refusing from } \\
\text { investment in } \\
\text { Stage } 3.2\end{array}$ & $\begin{array}{l}\text { Value potential } \\
\text { losses from } \\
\text { investments in the } \\
\text { following stages }\end{array}$ & $\begin{array}{l}\text { Workers' salary } \\
\text { equipment wear costs } \\
\text { of experiments }\end{array}$ \\
\hline $\begin{array}{l}\text { 3.2. Development } \\
\text { work: } \\
\text { production of } \\
\text { prototypes; } \\
\text { development of } \\
\text { technology, design, } \\
\text { design } \\
\text { documentation; } \\
\text { development of the } \\
\text { regulatory guidance } \\
\text { documents; } \\
\text { conducting patent } \\
\text { research; } \\
\text { testing; } \\
\text { field supervision. }\end{array}$ & $\begin{array}{l}\text { Refusing from } \\
\text { investment in stage } \\
3.3\end{array}$ & $\begin{array}{l}\text { Value potential } \\
\text { losses from } \\
\text { investments in the } \\
\text { following stages }\end{array}$ & $\begin{array}{l}\text { Cost of work and } \\
\text { materials wear }\end{array}$ \\
\hline
\end{tabular}




\begin{tabular}{|c|c|c|c|}
\hline Steps & Real option & Real option value & Investments \\
\hline \multirow[t]{2}{*}{$\begin{array}{l}\text { 3.3. Economic } \\
\text { analysis of R\&D } \\
\text { results }\end{array}$} & $\begin{array}{l}\text { Delayed investment } \\
\text { in Stage } 4\end{array}$ & $\begin{array}{l}\text { The increase in NPV } \\
\text { due to more } \\
\text { successful timing for } \\
\text { net loss cash flows } \\
\text { deferment periods }\end{array}$ & \multirow[b]{2}{*}{$\begin{array}{l}\text { Cost of analytical } \\
\text { works, overhead } \\
\text { costs }\end{array}$} \\
\hline & $\begin{array}{l}\text { Refusing from } \\
\text { investment in } \\
\text { Stage } 4\end{array}$ & $\begin{array}{l}\text { Value potential } \\
\text { losses from } \\
\text { investments in the } \\
\text { following stages }\end{array}$ & \\
\hline \multicolumn{4}{|c|}{ 4. Stage of implementation and use of innovative product } \\
\hline \multirow[t]{2}{*}{$\begin{array}{l}\text { 4.1. Exploration and } \\
\text { trial production }\end{array}$} & $\begin{array}{l}\text { Change in product } \\
\text { design }\end{array}$ & $\begin{array}{l}\text { The increase in NPV } \\
\text { by acquisition of } \\
\text { expensive product } \\
\text { for additional } \\
\text { competitive benefits }\end{array}$ & \multirow{2}{*}{$\begin{array}{l}\text { Supply costs and } \\
\text { adjustment of } \\
\text { equipment purchase } \\
\text { of materials, raw } \\
\text { materials, costs of } \\
\text { energy, salaries } \\
\text { overhead costs }\end{array}$} \\
\hline & $\begin{array}{l}\text { Refusing from } \\
\text { investment in } \\
\text { Stage } 4.2 \text {. }\end{array}$ & $\begin{array}{l}\text { Value potential } \\
\text { losses from } \\
\text { investments in the } \\
\text { following stages }\end{array}$ & \\
\hline \multirow[t]{4}{*}{ 4.2. Test marketing } & $\begin{array}{l}\text { Corrective selling } \\
\text { strategy }\end{array}$ & $\begin{array}{l}\text { The increase by the } \\
\text { implementation of a } \\
\text { efficient marketing } \\
\text { strategies }\end{array}$ & \multirow{4}{*}{$\begin{array}{l}\text { Promotion costs, } \\
\text { costs of logistics of } \\
\text { production, fees and } \\
\text { interpretation on of } \\
\text { analytical } \\
\text { information }\end{array}$} \\
\hline & $\begin{array}{l}\text { Changing volumes } \\
\text { release }\end{array}$ & $\begin{array}{l}\text { The increase in NPV } \\
\text { through large } \\
\text { volume sales or } \\
\text { avoiding losses of } \\
\text { overproduction }\end{array}$ & \\
\hline & $\begin{array}{l}\text { Delayed investment } \\
\text { in Stage } 4.3 \text {. }\end{array}$ & $\begin{array}{l}\text { The increase in NPV } \\
\text { by more successful } \\
\text { choice of the time of } \\
\text { industrial release net } \\
\text { loss of cash streams } \\
\text { during periods delay }\end{array}$ & \\
\hline & $\begin{array}{l}\text { Refusing from } \\
\text { investment in } \\
\text { Stage } 4.3 \text {. }\end{array}$ & $\begin{array}{l}\text { Value potential } \\
\text { losses from } \\
\text { investments in the } \\
\text { following stages }\end{array}$ & \\
\hline $\begin{array}{l}\text { 4.3. Industrial } \\
\text { production }\end{array}$ & - & - & $\begin{array}{l}\text { Costs of adjustment } \\
\text { equipment } \\
\text { agreements on } \\
\text { production processes, } \\
\text { purchase of materials } \\
\text { and raw materials, } \\
\text { energy, salaries, } \\
\text { overhead costs }\end{array}$ \\
\hline
\end{tabular}




\begin{tabular}{|c|c|c|c|}
\hline Steps & Real option & Real option value & Investments \\
\hline \multirow[t]{3}{*}{ 4.4. Marketing } & $\begin{array}{l}\text { Corrective selling } \\
\text { strategy }\end{array}$ & $\begin{array}{l}\text { The increase in NPV } \\
\text { by implementing of } \\
\text { efficient marketing } \\
\text { strategies }\end{array}$ & \multirow{3}{*}{$\begin{array}{l}\text { Costs of promotion, } \\
\text { Costs of production } \\
\text { logistics }\end{array}$} \\
\hline & $\begin{array}{l}\text { Changing volumes } \\
\text { release }\end{array}$ & $\begin{array}{l}\text { The increase in NPV } \\
\text { through large } \\
\text { volumes sales or } \\
\text { avoiding losses of } \\
\text { overproduction }\end{array}$ & \\
\hline & Conservation & $\begin{array}{l}\text { Value potential } \\
\text { losses from } \\
\text { overproduction } \\
\text { unclaimed } \\
\text { production, increase } \\
\text { in NPV by restarting } \\
\text { production in } \\
\text { appropriate that time }\end{array}$ & \\
\hline \multicolumn{4}{|l|}{ 5.Stage of completion } \\
\hline $\begin{array}{l}\text { 5.1. Liquidation, } \\
\text { terminating the use of } \\
\text { innovative products }\end{array}$ & - & - & $\begin{array}{l}\text { Liquidation costs, } \\
\text { termination of use of } \\
\text { innovative products }\end{array}$ \\
\hline $\begin{array}{l}\text { 5.2. Summing up the } \\
\text { results in terms of } \\
\text { obtaining the } \\
\text { expected } \\
\text { effectiveness of the } \\
\text { project }\end{array}$ & - & - & $\begin{array}{l}\text { Cost of analytical } \\
\text { works, overhead } \\
\text { costs }\end{array}$ \\
\hline
\end{tabular}

Note: compiled by the author.

The costs of Stage 1, Stage 2.1 - Stage 2.4 of an innovation project make basic investments that are performed almost by any construction enterprise. In Stage 1, there are only two options, making it possible to initiate the innovative project sooner or later, or refuse to implement it. In Stage 2.5 all the proposed ideas have been selected, in Stage 2.4 only the most workable idea should be chosen. Costs are relatively low in executions of works in this stage. In stage 2.7 technical and feasibility study on the present value of the defined innovative project is carried out. R\&D stage can be defined as the stage of development of ideas. The end of this stage gives us a comprehensive vision of innovative project in construction with all the associated technical and economic documentation and comparison with market realities. This allows one to make the decision on the implementation of the first significant investment. It is necessary to acquire fixed assets, to envisage the formation personnel, development, pilot production and test marketing.

Before moving in-to industrial production and carrying out the second significant investments in Stage 4.2, the test results are processed through marketing. At this stage a second significant adjustment may be made in innovative project management strategy. Test marketing includes the following 
options: corrective selling strategy, change of production volumes, the delayed investment in Stage 4.3, refusing from investment in Stage 4.3.

In the stage of completion of the innovative project new appliances are written off (eliminated), the use of technology and other innovative products is stopped, an innovative projects summed up in terms of achieving its goal, obtaining of the expected effectiveness of the project, therefore, consideration of the actual options at this stage seems inexpedient.

\subsection{Methods of Calculating Real Options}

The important advantage of using the method of real options is the possibility of the adoption of flexible management decisions under conditions of high uncertainty for making the financing of innovative projects in construction. That is particularly important in the case of venture projects in the early stages, where the level of such uncertainties and the risk is extremely high. In addition, the real options method takes into account a greater number of factors: the period during the retained investment opportunity, the uncertainty of future revenue, the current value of future cash flows. The analysis of the possibilities of practical application of the real options method showed the feasibility of two main models of real options: assessment of innovative projects in the construction and validation of an effective strategy for stepwise investment venture projects:

1. Black - Scholes model (Black Scholes options pricing model, BSOPM),

2. Binomial model (Binomial options pricing model, BOPM).

In the first model the real option is seen as a European koll option and its value is calculated according to the formula (Selina, 2014):

$$
\begin{aligned}
& C_{0}=S_{0} \Phi\left(d_{1}(T)\right)-I_{0} e^{-r f T} \Phi\left(d_{2}(T)\right) \\
& d_{1}(T)=\frac{\ln \left(S_{0} / I_{0}\right)+\left(r f+\sigma^{2} / 2\right) t}{\sigma \sqrt{t}} \\
& d_{2}(T)=d_{1}(T)-\sigma \sqrt{t}
\end{aligned}
$$

where

$C_{0}$ - the current price of the call option;

$S_{0}$ - the current price of the basic asset (the current price of the present value of cash flows after investments);

$\Phi\left(d_{1}(T)\right), \Phi\left(d_{2}(T)\right)$ - cumulative function of normal distribution;

$t, T$ - the time of execution of a koll option;

$I_{0}$ - the option exercise price (the size of investments);

$e$ - the base of natural logarithm $(e=2.718)$;

$\sigma-$ standard deviation of the price of the basic asset, the share units.

$$
r f=\ln (1+r)
$$


where

$r f$ - the risk - free rate of return calculated by the method of continuous percentage;

ln - a sign of the natural logarithm;

$r$ - risk-free annual rate of return, share units.

However, in author's opinion, using Black - Scholes formula for the valuation of real options of innovative projects causes the following difficulties:

- evaluation is a European option with a specific execution date, but most of the innovative projects of real options are American options and are not limited to a specific execution date;

- using the Black - Scholes formula the basic asset should be freely traded on the market. In the case of assessment of real options basic asset of innovative projects is not publicly traded, it is not necessary in a free market of the basic asset to create replication portfolio valuation and real options;

- the price of the asset must be continuous, if this assumption is violated, the model underestimates the cost of stock options - a prerequisite is not valid for almost all real options;

- standard deviation is known and does not change during the life of the option. This assumption is not true in the case of real options of long-term innovative projects, as there is a strong probability of the standard deviation of the change;

- the option must be executed immediately, which is not true for real options of innovative projects. For example, real option execution of innovative projects in construction cannot be instantaneous.

The above conditions of Black - Scholes model significantly narrow its scope to assess the real options of innovative projects. However, given the value of the theory of the Black - Scholes MODEL, many researchers have paid considerable attention to the formula (1), introducing amendments thereto, which allow closer assumptions of the model to real life. As a result, there is the complication of the mathematical apparatus, so further study will focus more on the actual binomial option model.

The binomial model is based on building a binary tree of decision and iterating through scenarios based on probability optimistic and pessimistic development of events to determine the value of real option. The use of a binomial model (BOPM) is a more appropriate way to evaluate the venture innovation projects in construction. The main advantage of this model is the ability to track changes in the price of the basic asset at the time, which allows to evaluate not only the European options (with a fixed date of performance), and American options, including the model of an unstable dispersion, but also to take into account changes in the exercise price, which cannot be reflected when using the Black - Scholes model. Also, BOPM allows to get more accurate results in the case of a few sources of uncertainty or a large number of decision - making dates (Socolova, 2012).

To calculated the cost of the option in BORM is to construct a binomial scheme, where at each point the calculated cost of the project, the present value of 
all cash flows in the event of changes in the situation is shown. The aim is to take the most effective solution for each node circuit, which means considering the risks. The assessment is complicated by the increasing number of periods, as it becomes more difficult to assess the probability characteristics, values relative to the growth and reducing of the project cost (Ziyatdinov, 2010).

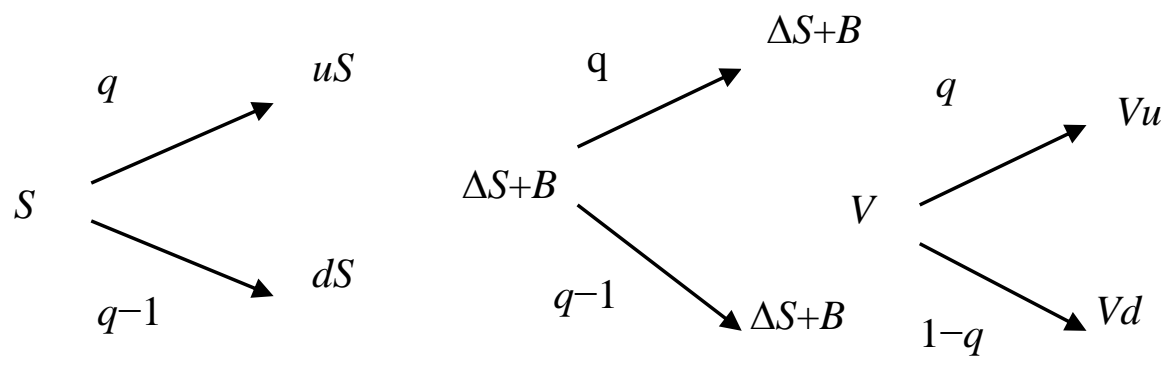

Fig. 1. The binomial scheme.

Fig. 1 shows the binomial scheme where:

$S$ - the price of the basic asset at time $t$;

$q-$ the probability of price increase;

$1-q-$ the probability of price decrease;

$u=1 / d-$ growth factor;

$d=1 / u-$ reduction factor;

$V$ - value of the option;

$V u, V d-$ possible future values of the option payments.

Binomial model involves the determining of the value of the option on the basis of the construction of tree changes in the value of the basic asset at the time using the growth $(u)$ and the reduction factor $(d)$. The values of $(u)$ and $(d)$ are determined based on the assumption that the price change of the underlying asset can be described by geometric Brownian motion and are using the following formulas (Selina, 2014):

$$
u=e^{\sigma \sqrt{h}}
$$

where

$u$ - increasing factor;

$e-$ base of natural logarithms;

$\sigma-$ standard deviation of the price of the basic asset, the proportion of units;

$h-$ the execution of a koll option.

$$
d=1 / u
$$

where

$d$ - reduction factor and;

$u$ - is growth factor.

These factors are constant on any of the lattice nodes.

Valuation of the option, as in the case of the Black - Scholes model, is based on the construction of the replication portfolio, consisting of $D$ shares with the 
current price of $S$ and the amount of $B$, invested in risk-free bonds with interest rate $r$. The profitability of this portfolio repeats the profitability option. This approach makes the model regardless of the frequency probability $q$. The construction of the replication portfolio is carried out in each of the nodes of the lattice binomial, except the extreme right, where possible payment of the option determined is based on the obtained value of the underlying asset value. Thus, gradually calculating the option value (payments) at the lattice sites and "turning" model from right to left, we find the desired value - value of the option at time $t_{0}$.

Assuming that we know the value of possible future benefits of the option $V u$ and $V d$, we find the values of $D$ and $B$ of the following equations:

$$
\begin{aligned}
& V u=\Delta u S+(1+r) \times B \\
& V d=\Delta d S+(1+r) \times B
\end{aligned}
$$

where

$V u, V d$ - possible future payments of the option;

$S$ - the current share price;

$B$ - amount invested in risk-free bonds;

$r$ - rate of risk - free bonds.

As a result, we obtain the solution of the system:

$$
\begin{aligned}
& D=\frac{V u+V d}{(u-d) \times S} \\
& B=\frac{u V u+d V d}{(u-d)(1+r)}
\end{aligned}
$$

Now, finding the parameters of the replication portfolio, we can determine the current value of option:

$$
V=D S+B
$$

where

$V$ - the current value of the option;

$D$ - number of shares;

$S$ - the current share price;

$B$ - amount invested in risk - free bonds.

Calculation of the parameters of the replication portfolio for each lattice site greatly complicates the evaluation process, as often the model includes more than one period and a larger number of nodes, but there are methods of calculation, allowing to avoid it.

The basis of the present value of the option is the size of potential future payments on it, which should be brought to this point in time, that is, to carry out the discounting of future cash flows (CIF - Cash - in Flow):

$$
V=[q V u+(1-q) \times V d] \times \frac{1}{(1+i)^{t}}
$$


where

$q$-is frequency probability and;

$i-$ is discount rate of expected return, which takes into account the possible risks.

The main difficulty of this approach is the determination of the discount rate, which will take its value for each node of binomial lattice. To overcome this complexity allows the use of so-called risk - neutral approach, where discounting at the risk-free rate as a reflection of risk factors is done by the risk - neutral probability $p$, reflecting the likelihood of the risk-free situation.

Substituting in the expression $V=D S+B$ the obtained values for $D$ and $B$, define the value of the risk - neutral probability $p$, which reflects the probability of the risk - free situation:

$$
\begin{aligned}
& V=\left[\left(\frac{1+r-d}{u-d}\right) V u+\left(\frac{u-(1+r)}{u-d}\right) V d\right] \\
& V=\frac{p V u+(1-p) V d}{1+r} \\
& P=\frac{1+r-d}{u-d}
\end{aligned}
$$

The resulting risk - neutral probability, provides that $V u$ and $V d$ are known, can be used to calculate the expected value of the option at the time $t_{0}$ replication without building a portfolio. The discount rate, in this case the risk-free rate, will be applied. The values of $p$ and $(1-p)$ will be constant for all the lattice sites, which greatly simplifies and accelerates the calculation, allowing for each lattice site to use the formula:

$$
V i j=\frac{p \times V(i+1) j+(1-p) \times V(i+1)(i+1)}{1+r f}
$$

where

$r f$ - risk - free annual interest rate of return.

On the one hand, the binomial model allows to visualize the possible scenarios of the development of the project, which facilitates the interpretation of results and decision making, on the other hand, requiring more calculations.

\section{RESULTS}

Application of the real option method is useful when there is a high degree of uncertainty of results of the project, the possibility to make flexible decisions when new information and the negative value of NPV (net present value) appear in the project. The analysis of real options is particularly useful in assessing the value of venture investment in construction, the commercial viability of which is very difficult to prove in the development phase (Ferzalieva, 2011). 
Real options allow increase in the value of innovative projects using venture investment due to the active risk-management, which is the value of the innovative project and the basis for economic growth. Depending on external conditions the implementation of innovative project using venture investment may be decided on the execution or refusing of the implementation of real options, designed at the initial stage of the analysis of innovative project. The main objective of real options is to protect investors' interests when changing the conditions for the realization of innovative projects. The cycle of risk management of innovative venture project in construction using the real option method consists of the following steps: analysis of the innovative project using venture investment, the identification of risks, qualitative and quantitative assessment of risk - management strategy formation, incorporation of real options, evaluation of effectiveness of the real options method.

Thus, this article analyzes the main methods of risk assessment in construction, and the real options method is selected as the primary one. The author describes model assessment of real options. The binomial model is defined as an estimate of the real options because of its clarity and simplicity in calculations.

\section{CONCLUSION}

The method of real option is an important tool for innovative project management using venture investment at all stages. However, application of real option to evaluate the actual innovative project is not always advisable. It makes sense to use it if:

- the level of project's uncertainty is high, but part of it can be resolved if new information becomes available in the future;

- the management has the ability to carry out administrative influence;

- project can be implemented in several stages;

- future investment success depends on this investment.

The above conditions are present in innovative projects using venture investment, but compliance with the first two conditions is necessary. The presence of high level of uncertainty by implementation of the project in construction is not in doubt. So, using the real option method is topical in construction.

The method of real option may provide a more accurate assessment of risk analysis in the development of innovative projects, and in general, can be a catalyst for innovative development of the economy (Decree of the Ministry of economical development of the Russian Federation, 2010). By learning to find hidden opportunities in an innovative project, the project manager receives the indubitable benefits, as he can intuitively estimate the benefits of various options. 


\section{ACKNOWLEDGMENT}

The present research has been supported by the Russian Humanitarian Scientific Fund $(R G N F)$ within the project "Development of Ecological-Economic Methods of Energy Innovation Management in the Building Materials Industry” No. 15-32-01383.

\section{REFERENCES}

Decree of the Ministry of economical development of the Russian Federation. (2010). The strategy of innovation development of the Russian Federation for the period till 2020.

Ernst \& Young Global Limited using Russian Venture Company. (2014). Study Russian and world venture capital market for the years 2007-2013.

Ferzalieva, A. O. (2011). Evaluating the effectiveness of innovative projects based on the use of real option. Management of economic systems Journal, 12(36). Retrieved from http://www.uecs.ru/uecs-36-122011/item/889-2011-12-22-08-18-37

Selina, V. P. (2014). The theory of real options and financial risk management of development projects. Candidate dissertations.

Socolova, Ju. V. (2012). Development of venture financing: the forms of organization, discrete method of financing. Management of economic systems Journal, 12(48). Retrieved from http://www.uecs.ru/marketing/item/1910-2012-12-26-12-31-42

The Federal Agency for Innovation and Development of Economic and Social projects. (n.d.). Retrieved September 14, 2016, from www.innoros.ru

Vladimirova, I. L., \& Pugacheva, V. S. (2013). The main principles of a comprehensive evaluation of the effectiveness using venture investment in innovative projects in construction .Bulletin of Russian Plekhanov University of Economic, 2(56), 32-38.

Zakieva, N. M. (2012). Real options as a methodological framework of innovation project management. New KGASU, 3(21), 183-193.

Ziyatdinov, A.Sh. (2010). Real options method for the evaluation of investment projects. Economics and Management Journal, 3(64), 147.

\section{AUTHOR'S SHORT BIOGRAPHY}

Valeria S. Pugacheva is a Postgraduate student of the Department of Project and Program Management in Russian Plekhanov University of Economics. The author has 9 publications. The area of her scientific interests is venture investment in construction and assessment of innovative projects in construction. She has participated in the project "Development of Ecological-Economic Methods of Energy Innovation Management in the Building Materials Industry" of the Russian humanitarian Scientific Fund.

Address: Str. Kashirskoe shosse, 49-8, Domodedovo, Moscow Region, 142000 Russian Federation,

Phone: +7905 5202404 